\title{
Erratum to: Idelalisib: First Global Approval
}

\author{
Anthony Markham
}

Published online: 7 October 2014

(C) Springer International Publishing Switzerland 2014

\section{Erratum to: Drugs (2014) 74:1701-1707 \\ DOI 10.1007/s40265-014-0285-6}

Page 1701, abstract, lines 4-8: The following sentence, which previously read:

It has received its first approval in the US in July 2014 for the treatment of relapsed chronic lymphocytic leukaemia (CLL), relapsed follicular B-cell non-Hodgkin lymphoma (NHL) and relapsed small lymphocytic leukaemia (SLL).

Should read:

It has received its first approval in the US in July 2014 for the treatment of relapsed chronic lymphocytic leukaemia (CLL), relapsed follicular B-cell non-Hodgkin lymphoma (NHL) and relapsed small lymphocytic lymphoma (SLL).
Page 1701, section 1, paragraph 2, lines 5-9: The following sentence, which previously read:

The drug has also been granted accelerated approval in patients with relapsed follicular B-cell non-Hodgkin lymphoma (NHL) and relapsed small lymphocytic leukaemia (SLL) who have received at least two other prior therapies $[3,4]$.

Should read:

The drug has also been granted accelerated approval in patients with relapsed follicular B-cell non-Hodgkin lymphoma (NHL) and relapsed small lymphocytic lymphoma (SLL) who have received at least two other prior therapies $[3,4]$.

The online version of the original article can be found under doi:10.1007/s40265-014-0285-6.

\footnotetext{
A. Markham $(\bowtie)$

Springer, Private Bag 65901, Mairangi Bay,

0754 Auckland, New Zealand

e-mail: dru@adis.com
} 